\title{
PELATIHAN USAHA KECIL MENENGAH IBU PKK KELURAHAN BANJAR SARI, METRO UTARA
}

\author{
Desi Derina Yusda ${ }^{1}$, Tyas Desita Wengrum ${ }^{2}$, Hikmah Justiti Adiastuti ${ }^{3}$, \\ Eka Travilta Oktaria ${ }^{4}$, Pipit Novilasari ${ }^{5}$ \\ ${ }^{1,2,3)}$ Program Studi DIII Manajemen Industri, Fakultas Bisnis, Universitas Mitra Indonesia \\ ${ }^{4,5)}$ Program Studi DIII Akuntansi, Fakultas Bisnis, Universitas Mitra Indonesia \\ e-mail: desiderina@umitra.ac.id
}

\begin{abstract}
Abstrak
Kebijakan pemberdayaan usaha kecil menengah secara umum diarahkan untuk mendukung upaya-upaya penanggulangan kemiskinan dan kesenjangan, penciptaan kesempatan kerja dan peningkatan ekspor, serta revitalisasi pertanian dan perdesaan, yang menjadi prioritas pembangunan nasional. Pemberdayaan tersebut dapat didukung melalui pelatihan keterampilan masyarakat guna menciptakan kesempatan lapangan kerja. Pelatihan ini diberikan pada 30 orang Ibu PKK Kelurahan Banjar Sari, Metro Utara. Tujuan dari kegiatan ini adalah memberikan pengetahuan dan keterampilan kepada Ibu PKK akan usaha kecil menengah dan memberikan contoh kerajinan tangan sederhana kain flanel yang dapat dijadikan usaha oleh Ibu PKK, pelatihan tersebut melalui metode ceramah, demonstasi dan diskusi. Materi disampaikan oleh Dosen Prodi DIII Manajemen Industri dan DIII Akuntansi, Fakultas Bisnis, Universitas Mitra Indonesia. Hasil dari kegiatan ini diharapkan akan meningkatkan pengetahuan dan keterampilan akan UKM serta kewirausahaan untuk Ibu PKK di Kelurahan Banjar Sari, Metro Utara, sehingga ibu PKK dapat menciptakan lapangan pekerjaan dan produk yang dihasilkan berdaya saing sehingga dapat memberi tambahan pendapatan baik secara individu maupun kelompok.
\end{abstract}

\section{Kata Kunci : UKM, Kewirausahaan}

\begin{abstract}
The policy for empowering SME in general is directed at supporting efforts to reduce poverty and inequality, create job opportunities and increase exports, as well as revitalize agriculture and rural areas, which are national development priorities. This empowerment can be supported through community skills training to create job opportunities. This training was given to 30 PKK's grup of Banjar Sari Village, Metro Utara. The purpose of this activity is to provide knowledge and skills to PKK's grup about small and medium enterprises and provide examples of simple flannel handicrafts that can be used as a business for PKK's grup, the training is through lecture methods, demonstrations and discussions. The material was delivered by the Lecturer in Industrial Management and Accounting, Faculty of Business, Universitas Mitra Indonesia. The results of this activity are expected to increase the knowledge and skills of SME and entrepreneurship for PKK's grup in Banjar Sari Village, Metro Utara, so that PKK's grup can create jobs and products that are competitive so that they can provide additional income.
\end{abstract}

Keywords: SME, Entrepreneurship

\section{PENDAHULUAN}

Pembangunan ekonomi di Indonesia tidak lepas dari peranan usaha mikro kecil dan menengah karena hal tersebut sangat membantu negara dalam penyerapan tenaga kerja yang cukup banyak di Indonesia. UMKM merupakan salah satu alternatif yang dapat memberikan kontribusi dalam terciptanya peningkatan pendapatan masyarakat Indonesia (Indriyatni, 2013). Pada tahun 2018 daya serap tenaga kerja UMKM adalah sebanyak 97\% dari daya serap tenaga kerja dunia usaha. Sementara itu kontribusi UMKM terhadap perekonomian nasional sebesar $61,1 \%$, dan sisanya yaitu $38,9 \%$ disumbangkan oleh pelaku usaha besar yang jumlahnya hanya sebesar $0,01 \%$ dari jumlah pelaku usaha (www.djkn.kemenkeu.go.id). Indonesia dengan 
negara yang sangat luas dan banyak sumber daya alam yang dapat diolah menjadikan Indonesia menjadi ladang usaha yang sangat berpotensi khususnya untuk usaha mikro, kecil dan menengah. Selain sumber daya alam yang melimpah, masyarakat sudah semakin peka terhadap keterampilan dan kemampuan untuk mengelola sumber daya alam yang ada untuk dijadikan produk yang bermanfaat, berdaya saing dan ouputnya adalah masyarakat dapat menambah pendapatan (Tulus, 2012). Indonesia mempunyai potensi basis ekonomi nasional yang kuat karena jumlah UMKM terutama usaha mikro yang sangat banyak dan daya serap tenaga kerja sangat besar. Basis usaha ini juga terbukti kuat dalam menghadapi krisis ekonomi. Usaha mikro juga mempunyai perputaran transaksi yang cepat, menggunakan produksi domestik dan bersentuhan dengan kebutuhan primer masyarakat (www.djkn.kemenkeu.go.id).

Saat ini pekerjaan sebagai pengusaha atau wirausahawan mulai dilirik. Wirausahawan membantu membuka lapangan pekerjaan bagi orang lain. Wirausaha memiliki dua peran, secara mikro yaitu sebagai penemu (innovator) dan perencana (planner). Sebagai penemu, wirausaha menemukan dan menciptakan sesuatu yang baru, seperti produk, tekhnologi, cara, ide, organisasi, dan sebagainya. Sebagai perencana, wirausaha berperan merancang tindakan dan usaha baru, merencanakan strategi usaha yang baru, merencanakan ide-ide dan peluang dalam meraih sukses, menciptakan organisasi perusahaan yang baru, dan lain-lain. Secara makro, peran wirausaha adalah menciptakan kemakmuran, pemerataan kekayaan, dan kesempatan kerja yang berfungsi sebagai mesin pertumbuhan perekonomian suatu Negara (Suryana, 2008). Jika dilihat, masyarakat sudah sangat peka terhadap produk yang dihasilkan oleh negara kita sendiri atau yang sering disebut sebagai karya anak bangsa. Hasil dari produk yang diciptakan tidak selalu mahal namun dari keunikan dan dibuat secara handmade membuat produk tersebut banyak dicari oleh konsumen. Pemerintah mengatakan bahwa jika Indonesia akan maju dibutuhkan sekitar 4 juta orang pengusaha, artinya jumlah pengusaha di Indonesia masih jauh dari angka tersebut. Negara akan menjadi makmur jika minimal $2 \%$ dari persentase keseluruhan penduduk di negara tersebut menjadi wirausahawan. Indonesia sendiri sampai saat ini menurut sebuah riset jumlah penduduk yang menjadi wirausaha baru sekitar $0,18 \%$.

Salah satu sasaran yang harus diasah kemandiriannya melalui kegiatan berwirausaha adalah ibu-ibu Pemberdayaan Kesejahteraan Keluarga (PKK), Dosen D III Manajemen Industri dan D III Akuntansi Fakultas Bisnis memberikan pelatihan, praktik langsung kerajinan tangan serta diskusi bersama mengenai usaha mikro, kecil dan menengah serta membantu Ibu-ibu PKK agar jiwa kewirausahaan dapat tumbuh dan mulai menemukan ide UMKM, selain itu bagi ibuibu PKK yang telah memiliki UMKM juga diberikan materi mengenai pemasaran, yaitu strategi pemasaran. Materi yang diberikan dengan tujuan agar Ibu-Ibu PKK di Kelurahan Banjar Sari, Metro Utara yang telah memiliki gagasan usaha atau yang akan memulai usaha dapat merancang usahanya dengan baik serta nantinya dapat meningkatkan jumlah penjualan dari produk yang dihasilkan. Materi yang disampaikan kepada peserta juga bertujuan agar jiwa wirausaha dapat tumbuh dan ketika usaha tersebut sudah dibangun maka nantinya pelaku usaha dapat lebih jeli dan teliti dalam menciptakan strategi pemasaran yang tahan banting di tengah ketatnya persaingan pasar. Dalam kegiatan para peserta sangat antusias dalam mengikuti kegiatan. Dari kegiatan tersebut juga diadakan kegiatan keterampilan membuat berbagai produk dari kain flanel sebagai salah satu contoh usaha UMKM yang dapat dibuat oleh ibu-ibu Pemberdayaan Kesejahteraan Keluarga (PKK) Kelurahan Banjar Sari. Hasil dari pelatihan ini diharapkan agar ibu-ibu Pemberdayaan Kesejahteraan Keluarga (PKK) Kelurahan Banjar Sari Metro Utara dapat menumbuhkan jiwa kewirausahaan, memiliki pengetahuan dan keterampilan mengenai UMKM dan bagi Ibu PKK yang telah memiliki usaha agar dapat menerapkan strategi pemasaran agar usaha tersebut dapat bertahan seterusnya.

\section{METODE}

Kegiatan pengabdian ini dilakukan di Kelurahan Banjar Sari, Metro Utara dengan menggunakan beberapa tahap yakni ;

a. Tahap pertama yakni persiapan. Tahap ini diawali dengan melakukan survei awal yaitu 
melakukan diskusi dan koordinasi kepada Kepala Desa dan Ketua PKK Banjar Sari, Metro Utara untuk meminta izin melakukan PKM. Selanjutnya yaitu melihat kondisi di lapangan mengenai apa yang dialami oleh Ibu-Ibu PKK Banjar Sari dalam kesehariannya. Selain itu, tahap ini mencari persoalan-persoalan yang dihadapi oleh beberapa ibu-ibu PKK yang menjadi pelaku UMKM dalam menjalankan usahanya. Tahap persiapan lainnya adalah mengurus surat izin, surat tugas dan persiapan materi.

b. Tahap kedua, pelaksanaan. Dalam tahap ini pengabdian melalui pelatihan gabungan antara pelatihan bidang UMKM, konsep kewirausahaan serta praktek langsung keterampilan tangan. Kegiatan pengabdian dilakukan dengan metode ceramah yaitu pemberian pembekalan bidang UMKM secara umum, kewirausahaan, motivasi untuk memulai usaha baru atau pengembangan serta bagaimana agar dapat mempertahankan usaha UMKM yang ada dengan menentukan strategi yang tepat. Selain itu, kegiatan ini juga melakukan memberikan suatu keterampilan kerajinan tangan menggunakan kain flanel yang dibentuk menjadi sebuah gantungan kunci, amplop karakter untuk hari raya dan bungkus tempat tisu yang sangat menarik. Hal ini dilakukan untuk memberikan contoh ide produk untuk menggagas ibu-ibu PKK untuk memulai UMKM. Pada saat pemberian pelatihan tidak hanya tentang teori dan praktik kerajinan tangan tetapi juga dilakukan diskusi pembahasan masalah yang mereka hadapi selama ini dalam memulai usaha atau ketika menjalankan usaha.

c. Tahap ketiga, evaluasi. Pada tahap ini dilakukan evaluasi atas hasil yang telah dicapai oleh peserta pelatihan yaitu ibu-ibu PKK Banjar Sari, Metro Utara. Masukan dan perbaikan lebih lanjut dapat dilakukan pada tahap ini. Evaluasi diberikan dengan mengumpulkan data yang diperoleh dari kegiatan pelatihan. Data diambil dengan menyimpulkan pemahaman Ibu-Ibu PKK melalui kuesioner.

\section{HASIL DAN PEMBAHASAN}

Kegiatan pelatihan ini dilakukan di Aula Kelurahan yang biasa dipergunakan untuk kegiatan PKK. Aula tersebut beralamat di Jalan Pattimura No.51 Kelurahan Banjar Sari, Metro Utara. Kegiatan ini diikuti oleh 30 orang ibu-ibu PKK dan dilaksanakan pada tanggal 20 April 2020 dengan waktu jam 09.00 WIB sampai 16.00 WIB. Pelatihan berupa penyampaian materi tentang UMKM, kewirausahaan dan strategi pemasaran, lalu praktik langsung kerajinan tangan, dan selanjutnya ada diskusi untuk membahas masalah-masalah yang dihadapi oleh ibuibu PKK. Ternyata masalah yang paling banyak adalah bidang pemasaran, yaitu sulitnya mendapatkan tempat untuk berjualan, sulitnya memperluas pasar, ketidaktahuan untuk melakukan alat promosi dan pentingnya pengembangan produk. Selain dari itu pada bidang operasional adalah sulitnya mendapatkan supplier atau pemasok yang lokasinya dekat dengan tempat mereka berusaha dan masalah yang terakhir adalah kurangnya pengetahuan ibu-ibu PKK akan strategi wirausaha dan bagaimana caranya memiliki usaha dengan menerapkan strategi pemasaran agar usaha tersebut dapat bertahan. 


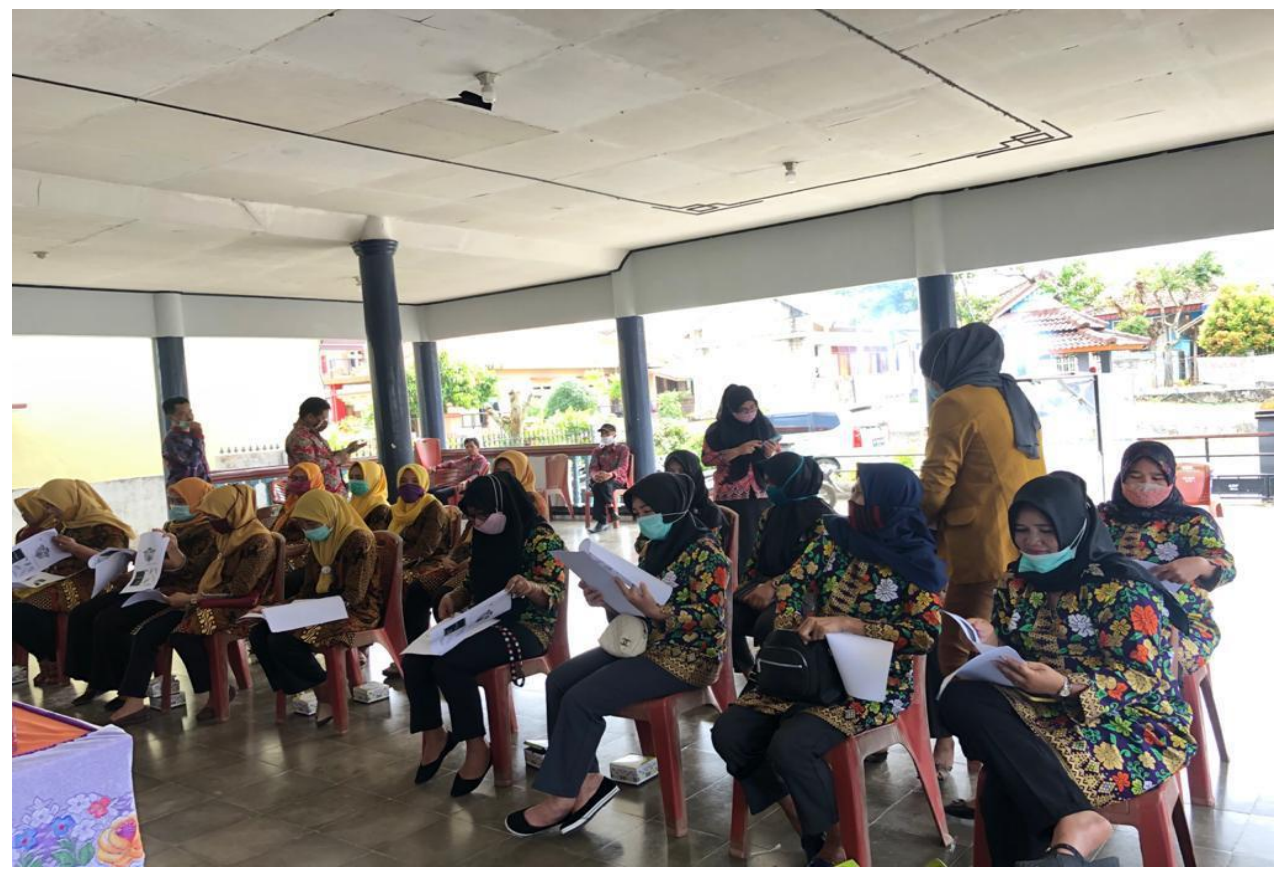

Gambar 1. Pembagian Materi ke Ibu-Ibu PKK Kelurahan Banjar Sari, Metro Utara

Kegiatan pelatihan ini berjalan dengan lancar dikarenakan adanya faktor yang mendukung berjalannya kegiatan pengabdian. Hal-hal yang mendukung berjalannya kegiatan pengabdian ini dapat diidentifikasi diantaranya antusisme para peserta pelatihan. Faktor yang mendukung kegiatan adalah antusiasme peserta untuk memahami materi menggembangkan dan meningkatkan jiwa kewirausahaan serta kemauan dari peserta pengabdian untuk memperhatikan penyampaian materi. Antusisme dibuktikan juga dengan banyaknya pertanyaan yang muncul ketika pelaksanaan diskusi kelompok dan pada saat praktik pembuatan kerajinan tangan. Terlihat dari awal hingga akhir acara, semua peserta mengikuti dengan baik. Berdasarkan hasil kegiatan dapat diidentifikasi mengenai tingkat pemahaman peserta adalah bahwa $95 \%$ peserta pengabdian memahami materi.

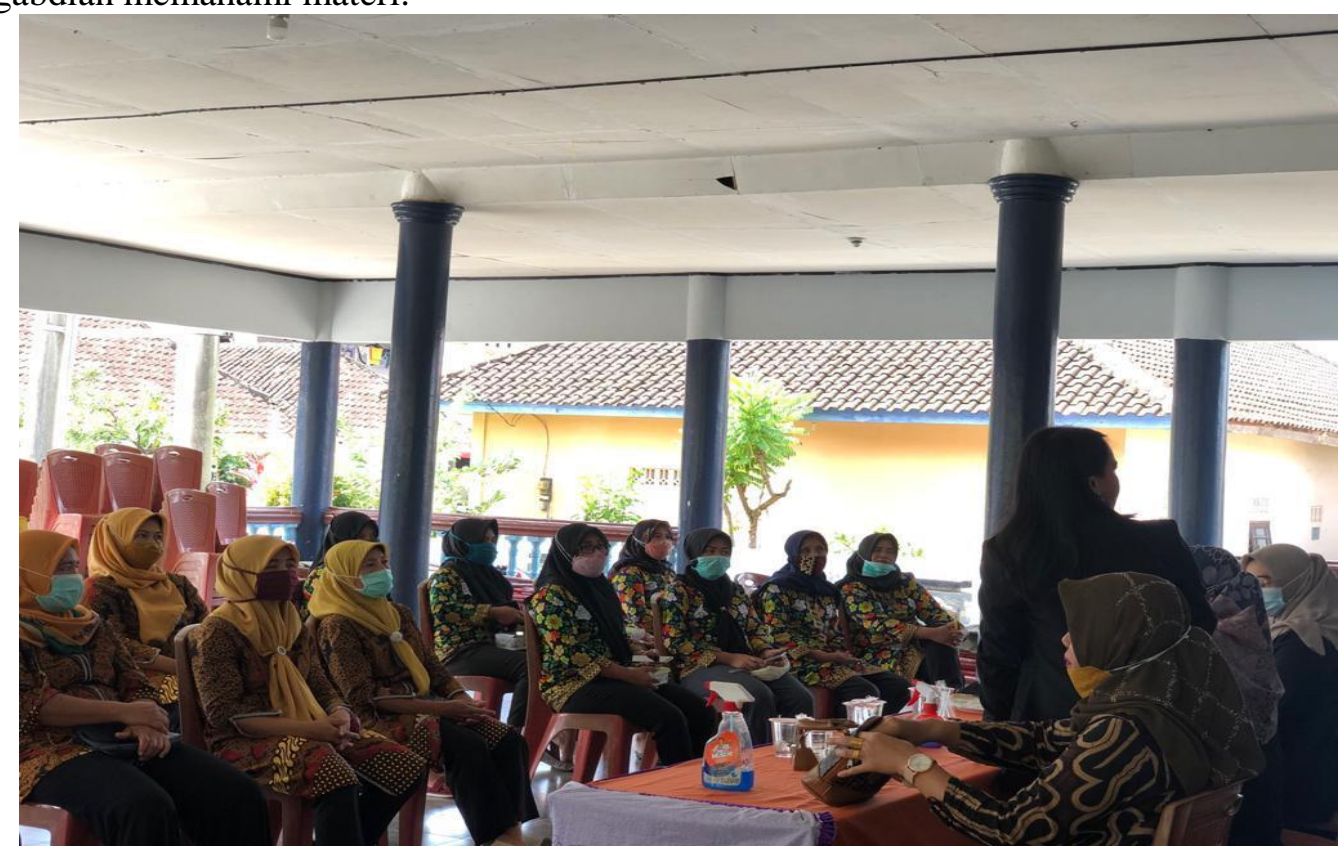

Gambar 2. Tim Pengabdian Sedang Menyampaikan Materi 
Harapan kami dengan pengabdian ini dapat membuka wawasan ibu-ibu PKK, bertambahnya keilmuan dan diharapkan mampu memberikan semangat baru untuk para ibu-ibu PKK dalam memulai usaha mikro, kecil dan menengah atau mengembangkan usaha yang ada agar kedepannya lebih dapat bertahan dan menimbulkan ide-ide untuk terus berinovasi. Selain itu untuk kami para dosen agar bisa lebih bermotivasi dalam menyampaikan materi dan berkontribusi bagi masyarakat.

\section{SIMPULAN}

Peserta memahami dan memiliki antusias tingi dalam mengikuti pelatihan mengenai usaha kecil, mikro dan menengah ini, peserta juga sangat senang dengan adanya keterampilan tangan sehingga peserta memiliki ide untuk inovasi atau memulai usaha, selain itu bagi peserta yang telah memiliki usaha dapat menerapkan strategi pemasaran yang tepat untuk usahanya.

\section{SARAN}

Setelah pengabdian ini diharapkan peserta agar lebih segera menindak lanjuti permasalahan yang ada diusahanya dan memiliki strategi pemasaran yang tersusun, mengingat sudah bertambahnya wawasan peserta dari pelatihan tersebut. Tim pengabdian agar terus melakukan kegiatan-kegiatan serupa secara berkesinambungan di masa yang akan datang.

\section{UCAPAN TERIMA KASIH}

Ucapan terima kasih tim pengabdian ucapkan kepada Kepala Desa dan Ketua Pemberdayaan Kesejahteraan Keluarga (PKK) Banjar Sari, Metro Utara yang sudah memberikan kesempatan dan dukungan untuk pengabdian ini.

\section{DAFTAR PUSTAKA}

Indriyatni, Lies. (2013). Analisis Faktor-Faktor yang Berpengaruh Terhadap Keberhasilan Usaha Mikro dan Kecil (Studi Pada Usaha Kecil Di Semarang Barat). Jurnal Volume 5 ,No 1 .

Suryana (2008) Kewirausahaan Pedoman Praktis: Kiat dan Proses Menuju Sukses, Jakarta: Salemba Empat.

Tulus Tambunan (2012) Usaha Mikro Kecil dan Menengah di Indonesia: Isu-Isu Penting, Jakarta: LP3ES

www.djkn.kemenkeu.go.id, tanggal 21 Maret 2018

www.djkn.kemenkeu.go.id, tanggal 4 April 2020 